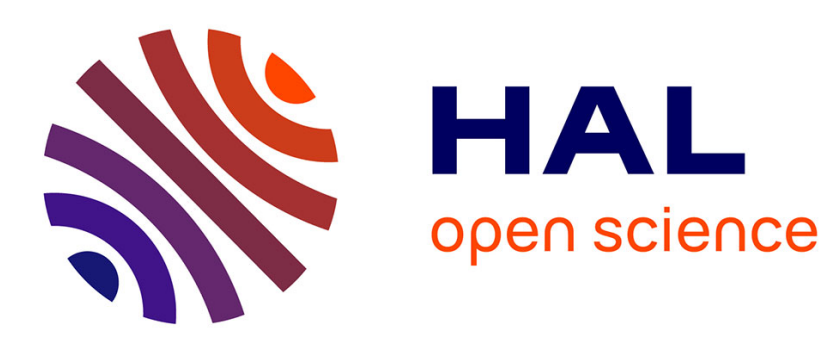

\title{
The development of the DDG-capability in firms: An evaluation of its impact on firm financial performance
}

Elisabetta Raguseo, Claudio Vitari

\section{To cite this version:}

Elisabetta Raguseo, Claudio Vitari. The development of the DDG-capability in firms: An evaluation of its impact on firm financial performance. 2013. hal-00969190

\section{HAL Id: hal-00969190 \\ http://hal.grenoble-em.com/hal-00969190}

Preprint submitted on 2 Apr 2014

HAL is a multi-disciplinary open access archive for the deposit and dissemination of scientific research documents, whether they are published or not. The documents may come from teaching and research institutions in France or abroad, or from public or private research centers.
L'archive ouverte pluridisciplinaire HAL, est destinée au dépôt et à la diffusion de documents scientifiques de niveau recherche, publiés ou non, émanant des établissements d'enseignement et de recherche français ou étrangers, des laboratoires publics ou privés. 


\title{
The development of the DDG-capability in firms: An evaluation of its impact on firm financial performance
}

\author{
Elisabetta Raguseo ${ }^{1}$, Claudio Vitari ${ }^{2}$ \\ ${ }^{1}$ Politecnico di Torino, Torino, Italy \\ \{elisabetta.raguseo@polito.it\} \\ ${ }^{2}$ Grenoble Ecole de Managament, Grenoble, France \\ \{claudio.vitari@grenoble-em.com\}
}

\begin{abstract}
We examine whether firms that develop the Digital Data Genesis dynamic capability show higher performance. Using detailed survey data on the capabilities developed by companies by the usage of digital data and firm financial performance of 96 firms, we find that the firms that develop the DDG dynamic capability have levels of ROA, ROS and revenue growth higher than others do. Our results provide one of the first empirical evidence on the direct link between DDG dynamic capability and firm financial performance.
\end{abstract}

Keywords. Digital Data Genesis; dynamic capabilities; Firm financial performance.

Research supported by French Rhône Alpes region (http://www.rhonealpes.fr/).

\section{Introduction}

Explaining the variation in the degree of success of business organizations is an evergreen issue in management research, including Information Systems and Strategic Management. Management scholars generally recognize that organizational capabilities can be a major source of firm performance [1], and previous studies have made great strides to extend and refine the conceptualizations and definitions of various types of capabilities (generic, organizational, ordinary, dynamic, heterogeneous, and homogeneous). Specifically, dynamic capabilities have been linked to firm performance in several studies [2], but their contribution is contested, as a firm's ability to deliver superior process performance in a competitive environment does not automatically imply it can achieve sustained competitive advantage, as several variables may intervene to prevent the latter [3, 4]. The concept of dynamic capabilities remains a debated and at times unclear research construct. Therefore, research in this area is clearly important. Hence, in this article, we seek to contribute to the emerging literature on Information Technology 
(IT) dynamic capabilities and their impact on firm financial performance. In addition, we innovate in the choice of the dynamic capability object of our study: Digital Data Genesis (DDG) [5]. We define DDG as the coming into being of digital data. Specifically, DDG represents the naissance of digital data: it is a phenomenon (an observable fact or event) that involves the direct generation of new data in digital form, and takes place when information representative of a physical action, event or condition is created digitally concurrently with the event taking place. DDG thus enables real time digital representations of objects and events - so that these objects and events can exist as symbolic representations that can interact and be manipulated in the information space. For example, when a waiter takes an order using a palm device, an informational representation of the customer wishes is created in real-time in digital form.

Since dynamic capabilities allow organizations to reconfigure organizational capabilities in response to changes in the business environment, and since data is a precursor to many organizational processes, we decided to study DDG dynamic capability. Indeed, we believe that data can really provide higher financial performance to firms, since nowadays IT solutions are pervasive and ubiquitous and all business or social activities are now generating a corresponding digital data event. Nevertheless, to the best of our knowledge, there is scant evidence in the literature on whether the usage of digital data can provide firms better financial performance. An additional reason to study the emerging DDG dynamic capability. Specifically, we investigate the following research question on a sample of 96 West-European companies: does DDG dynamic capability contribute positively to firm financial performance?

\subsection{DDG as dynamic capabilities}

Organisations need to constantly match or create market changes and dynamic capabilities are "the firm's processes that use resources - specifically the processes to integrate, reconfigure, gain and release resources - to match and even create market change" [6]. Thus, dynamic capabilities have the potential to create, to evolve and to recombine internal existing resources to allow the firm to adapt continuously to changes [7]. This adaptability has been argued as offering improved customer value [8], and is especially required in fast-paced technological environments [9].

We can define DDG dynamic capability as the three-fold organizational process of: 1) "choosing IT" in order to unobtrusively generate and capture data in digital form; 2) "reconfiguring IT" in the appropriate business processes; 3) "managing digital data" so produced. The technology embedded in a DDG initiative may be emerging IT - a new technology not yet commercially viable (e.g., retinal implants for blind people) - or may be an enabling IT: an established technology used by a firm in an innovative application (e.g., RFID in gaming chips to track table play in a gambling context).

We theorize DDG as a dynamic capability for two complementary reasons. First, it consists of deploying "new configurations of operational competencies relative 
to the competition" [10] - in other words, a firm with a DDG dynamic capability can identify opportunities for digital data generation and for recombining internal existing resources and data to adapt to changing environmental conditions, through the collection and production of new digital data. Second, the DDG dynamic capability includes the dynamic reconfiguring of the existing combinations of resources for digital data generation [10]. The degree to which an ineffective DDG process can be reconfigured into a more promising one that matches its environment, better, faster, and cheaper than the competition determines the capability's dynamic quality [6]. Therefore, the higher its degree of reconfigurability, the more dynamic the DDG dynamic capability is. Examples of DDG dynamic capabilities exist, such as the Harrah Corporation. For several years now, Harrah has systematically and repeatedly integrated new IT (such as computerized slot machines or RFID chips) to gain - unobtrusively, and always in new ways - valuable digital data on customers' behavior at the Harrah's casinos and exploits these new data to improve its customers' profiles and to better reward customers.

\subsection{The contribution of DDG Dynamic Capability on firm financial perform- ance}

Firms use dynamic capabilities to identify and react to opportunities and threats by extending, modifying, changing, and/or creating a firm's ordinary capabilities to accomplish first-order change [11]. This view is also consistent with the study conducted by Eisenhardt and Martin (2000: 1118), who argued that one could conceptualize dynamic capabilities as tools firms employed to manage and reconfigure existing resource in order to create new resource configurations.

Dynamic capabilities can contribute positively to firms' activities in several ways. First, firms thanks to the dynamic capabilities can improve the speed, effectiveness, and efficiency with which operate and respond to changes that they face in their environment [12]. As a result, this improved response speed, effectiveness, and efficiency with respect to dealing with environmental changes can positively affect firm financial performance by enabling the firm to take advantage of revenue enhancing opportunities and regulate its operations to reduce the incurred costs. Second, dynamic capabilities can positively affect firm financial performance by allowing the firm to recognize and react to opportunities through developing new processes, products, and services [13]. As a result, they have the potential to increase revenue. Third, dynamic capabilities offer new sets of decision options, previously unavailable for the firm, and thus provide the potential for greater firm financial performance contributions [6] such as increased revenues or profits. Therefore, dynamic capabilities can extend existing resource configurations in ways that result in entirely new sets of decision options in order to improve their process and product performance [6].

Based on these arguments, DDG dynamic capability could positively contribute to a firm's financial performance, because the process of choosing IT, managing digital data and reconfiguring digital data, could enable the firm to change its processes, products, and services, using the data in digital form, in order to achieve 
better financial performance. Therefore, we propose a positive relationship (Figure 1) between the DDG dynamic capability and the firm financial performance.

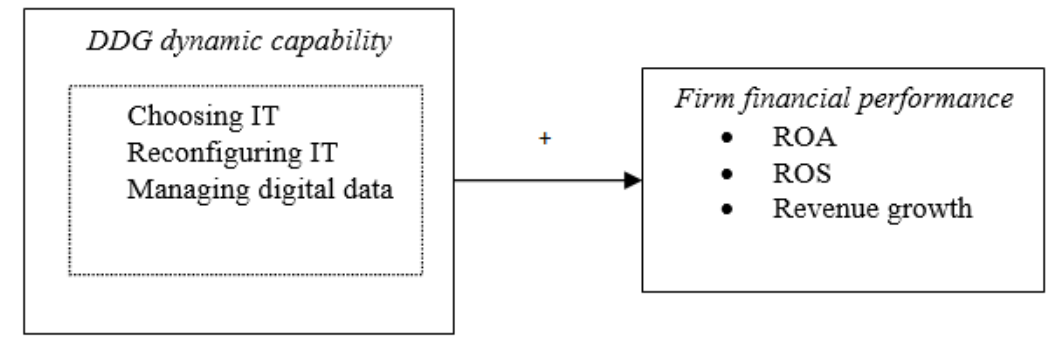

Fig. 1. Research model

\section{Methodology}

We conducted a questionnaire-based survey in 2012 of firms of any size and that belong to any industries, located in the West Europe, to test the supposed relationship. Given that the best approach to measure dynamic capabilities is at the organizational process level, our key informants were process managers in different companies. In particular, we selected sales managers as the sales department appeared as one of the departments more advanced in using DDG practices to improve customer relation [3]. We adopted the survey method as our main source of empirical data because it enables us to make a quantitative evaluation of the relationships between DDG dynamic capability and firm financial performance.

We operationalized measurement scales that already existed and had been tested for all the model's operationalized all the constructs of the model, with one exception: the 'choosing IT' construct of DDG dynamic capability, which measures the ability to choose IT to collect valuable digital data unobtrusively. We could not find any previously-tested scale for this construct in the literature, so we conducted preliminary testing via a pilot study. This pilot study started from four indicators which were available in the literature [14], but had never been tested empirically. We recruited 35 managers from small, medium and big enterprises in different industries to participate in the test, including the four indicators within a set of 26 other questions to reduce common method bias. Based on the 35 answers, the reliability of the scales satisfied the standard thresholds (Cronbach's Alpha = 0.837 ) and the scale was then reduced to two items. Specifically, it was operationalized by factoring the two items defined on a Likert scale between 1 and 7 . Instead, the existing scales cover the other variables:

1) Choosing IT: it measures the ability to choose emerging/enabling IT to gain unobtrusively valuable digital data [14]; 
2) Reconfiguring IT: it adapts the reconfigurability measurement scale [10] to estimate the potential to reconfigure DDG and it is operationalized by factoring two items defined on a Likert scale between 1 and 7;

3) Managing digital data: it adapts the information management dimension of the information capability measurement scale [15], to measure the ability to manage digital data and it is operationalized by factoring three items defined on a Likert scale between 1 and 7;

4) Digital Data Genesis Capability: it is operationalized by making the sum of the three variables Choosing IT, Reconfiguring IT and Managing digital data., and finally it was dichotomized on the median value of the variable;

5) Firm financial performance: we measured profitability using three measures of performance: (1) return on assets (ROA), (2) return on sales (ROS), and (3) sales growth in logarithmic form (SG) [16].

\section{Results and Analysis}

We collected 96 questionnaires for providing evidence on the relationship between the development of the DDG dynamic capability and the firm financial performance. The respondents were mainly sales department managers (27\%), senior sales managers (15\%), mid-level sales managers $(14 \%)$ and business unit managers responsible for sales (10\%). A broad range of industries were represented and the participating companies were of a wide variety of sizes. The descriptive statistics and the correlations between our variables are tabulated in Table 2 and 3. Specifically, the correlations between the dynamic capability investigated and the ROA, ROS and revenue growth positive and significant if we consider two of the three firm financial performance investigated in this paper: ROA and Sales growth.

Table 2. Descriptive statistics

\begin{tabular}{lccccc}
\hline Variable & Minimum & Maximum & Mean & Median & Std. Deviation \\
\hline ROA & -22.920 & 40.250 & 4.456 & 3.900 & 7.960 \\
ROS & -28.860 & 26.070 & 3.472 & 3.405 & 7.391 \\
Sales growth (log) & 8.900 & 37.670 & 22.019 & 16.209 & 9.227 \\
Choosing IT & 1.000 & 7.000 & 4.992 & 5.132 & 1.098 \\
Managing digital data & 1.330 & 7.000 & 5.036 & 5.148 & 1.011 \\
Reconfiguring IT & 2.000 & 7.000 & 4.585 & 4.632 & 1.081 \\
DDG dynamic capability & 0.000 & 1.000 & 0.260 & 0.000 & 0.441 \\
\hline
\end{tabular}

Table 3. Correlations between DDG dynamic capability and firm financial performance

\begin{tabular}{llccccccc}
\hline N. & Variable & 1 & 2 & 3 & 4 & 5 & 6 & 7 \\
\hline 1 & ROA & 1.000 & $0.837 * *$ & 0.161 & 0.104 & 0.060 & 0.132 & 0.178
\end{tabular}




\begin{tabular}{|c|c|c|c|c|c|c|c|c|}
\hline N. & Variable & 1 & 2 & 3 & 4 & 5 & 6 & 7 \\
\hline 2 & ROS & $0.837 * *$ & 1.000 & 0.187 & 0.035 & 0.094 & 0.057 & $0.229^{*}$ \\
\hline 3 & Sales growth & 0.161 & 0.187 & 1.000 & 0.064 & 0.087 & 0.109 & $0.265^{*}$ \\
\hline 4 & Choosing IT & 0.104 & 0.035 & 0.064 & 1.000 & $0.618 * *$ & $0.619 * *$ & $0.439 * *$ \\
\hline 5 & Managing digital data & 0.060 & 0.094 & 0.087 & $0.618^{* *}$ & 1.000 & $0.704 * *$ & $0.600 * *$ \\
\hline 6 & Reconfiguring IT & 0.132 & 0.057 & 0.109 & $0.619^{* *}$ & $0.704 * *$ & 1.000 & $0.695 * *$ \\
\hline 7 & DDG dynamic capability & 0.178 & $0.229 *$ & $0.265^{*}$ & $0.439 * *$ & $0.600 * *$ & $0.695 * *$ & 1.000 \\
\hline
\end{tabular}

**Correlation is significant at the 0.01 level, *Correlation is significant at the 0.05 level .

Since all the measures that were used for defining the construct related to the DDG dynamic capability were captured on 7-point Likert scales, we conducted confirmatory factor and reliability analysis (Table 4). They were satisfactory for the items that were used for defining each construct on which the DDG dynamic capability was defined. In terms of collinearity analysis, our tolerance value computations highlighted no risk of multicollinearity, with the correlation coefficients lower than 0.9 and the tolerance values above 0.19 .

Table 4. Factor and reliability analyses

\begin{tabular}{|c|c|c|}
\hline Construct names and construct's items & $\begin{array}{l}\text { Factor } \\
\text { load- } \\
\text { ing }\end{array}$ & $\begin{array}{c}\text { Cron- } \\
\text { bach's al- } \\
\text { pha }\end{array}$ \\
\hline Choosing IT & & 0.779 \\
\hline $\begin{array}{l}\text { Our Sales personnel have effective methods for the choices of } \\
\text { Digital Data Generation }\end{array}$ & 0.914 & \\
\hline $\begin{array}{l}\text { The choices of Digital Data Generation make their case for our } \\
\text { Sales process }\end{array}$ & 10 & \\
\hline Reconfiguring IT & & 0.871 \\
\hline $\begin{array}{l}\text { When our Digital Data Generation must evolve, our Sales per- } \\
\text { sonnel successfully steer its evolution }\end{array}$ & 0.945 & \\
\hline $\begin{array}{l}\text { When our Digital Data Generation must evolve, our Sales per- } \\
\text { sonnel effectively lead its reorganization }\end{array}$ & 0.950 & \\
\hline Managing digital data & & 0.879 \\
\hline $\begin{array}{l}\text { Our Sales personnel effectively handle the digital data that they } \\
\text { obtain }\end{array}$ & 0.937 & \\
\hline $\begin{array}{l}\text { Our Sales personnel effectively process the data obtained in dig- } \\
\text { ital form }\end{array}$ & 0.9 & \\
\hline $\begin{array}{l}\text { Our Sales personnel have effective methods for managing the } \\
\text { Digital Data that they obtain }\end{array}$ & 0. & \\
\hline
\end{tabular}

Our results regarding the level of firm financial performance achieved by companies that have developed the DDG dynamic capability and companies that have not developed such capability are shown in Table 5.

Table 5. Mean value of firm financial performance for companies that have developed and not the DDG dynamic capability

\begin{tabular}{lccccccc}
\hline & $\begin{array}{c}\text { DDG dynamic } \\
\text { capability }\end{array}$ & $\mathrm{N}$ & Mean & Std. Deviation & Min & Max & $\begin{array}{c}\text { Significance level } \\
\text { of the difference }\end{array}$ \\
\hline ROA & Low & 56 & 3.362 & 7.280 & -22.920 & 18.850 & \multirow{2}{*}{$5.02 \%$} \\
& High & 22 & 7.239 & 9.065 & -4.430 & 40.250 & \\
\hline ROS & Low & 56 & 2.420 & 6.941 & -28.860 & 18.020 & \multirow{2}{*}{$3.70 \%$}
\end{tabular}




\begin{tabular}{lccccccc}
\hline & $\begin{array}{c}\text { DDG dynamic } \\
\text { capability }\end{array}$ & $\mathrm{N}$ & Mean & Std. Deviation & Min & Max & $\begin{array}{c}\text { Significance level } \\
\text { of the difference }\end{array}$ \\
\hline Revenue & Low & 54 & 20.553 & 8.880 & 8.900 & 37.670 & $2.90 \%$ \\
growth $(\log )$ & High & 22 & 25.617 & 9.268 & 14.520 & 37.420 & \\
\cline { 2 - 6 } & & & &
\end{tabular}

Table 5 shows that companies that have developed the DDG capability (the case where the column "DDG dynamic capability" has the value "High") have achieved higher firm financial performance than the companies that have not developed DDG dynamic capability (column that has the "Low" value). Specifically, companies able to leverage on digital data have achieved higher ROA values (mean value equal to 7.239 regard the 3.362 - difference statistically significant at the $5.02 \%$ level), higher ROS values (mean value equal to 6.420 regard the 2.420 difference statistically significant at the level equal to the $3.70 \%$ level), and higher revenue growth (mean value equal to 25.617 regard the 20.553 - difference statistically significant at the $2.90 \%$ level).

\section{Discussions and conclusions}

The Information Systems and Strategic Management literature suggest a relationship between the dynamic capabilities and the financial performance achieved by firms. However, the literature is scant about empirical evidence on whether the development of DDG capability, leveraging on digital data, determines higher firm financial performance in firms. By analysing a sample of 96 companies, we find that DDG capability is associated with several measures of financial performance, such as the ROA, ROS and the revenue growth. Indeed, our results are consistent with several measures of financial performance.

The results that we found in this research study has important managerial implications. Indeed, managers of firms should become more aware about the potentiality that the usage of digital data can have on the activities that they conduct and should invest more in the capability of use this type of data. Indeed, they can be valuable for firms, as demonstrated in this research study. Future analyses will be based on qualitative studies, in order to understand how the capability emerges, develops and helps companies to gain better performance.

\section{References}

1. Peteraf, M.A., Di Stefano, G., Verona, G.: The Elephant in the Room of Dynamic Capabilities: Bringing Two Diverging Conversations Together. Strategic Management Journal (2013). In press. 
2. Drnevich, P.L., Kriauciunas, A.P.: Clarifying the conditions and limits of the contributions of ordinary and dynamic capabilities to relative firm performance. Strategic Management Journal 32, 254-279 (2011)

3. Kohli, R., Grover, V.: Business Value of IT: An Essay on Expanding Research Directions to Keep Up With The Times. Journal of the Association for Information Systems 9, 23-39 (2008)

4. Mithas, S., Ramasubbu, N., Sambamurthy, V.: How information management capability influences firm performance. MIS Quarterly 35, 237-256 (2011)

5. Piccoli, G., Watson, R.T.: Profit From Customer Data By Identifying Strategic Opportunities And Adopting The 'Born Digital' Approach. MIS Quarterly Executive 7, 113-122 (2008)

6. Eisenhardt, K. M., Martin J.A.M.: Dynamic capabilities: what are they?. Strategic Management Journal 21, 1105-1121 (2000)

7. Teece, D.J., Pisano, G., Shuen, A.: Dynamic Capabilities and Strategic Management. Strategic Management Journal 18, 509-533 (1997)

8. Sambamurthy, V., Bharadwaj, A., Grover, V.: Shaping agility through digital options: reconceptualizing the role of information technology in contemporary firms. MIS Quarterly 27, 237-263 (2003)

9. Banker, R.D., Bardhan, I.R., Hsihui, C., Shu, L.: Plant Information Systems, Manufacturing Capabilities, and Plant Performance. MIS Quarterly 30, 315-337 (2006)

10. Pavlou, P.A., El Sawy, O.A.: From IT Leveraging Competence to Competitive Advantage in Turbulent Environments: The Case of New Product Development. Information Systems Research 17, 198-227 (2006)

11. Dosi G., Nelson R., Winter, S.: Introduction: the nature and dynamics of organizational capabilities. In Nature and Dynamics of Organizational Capabilities. Oxford University Press, New York (2000)

12. Tallon, P.P.: Inside the adaptive enterprise: an information technology capabilities perspective on business process agility. Information Technology and Management 9, 21-36 (2008)

13. Zou, S., Fang, E., Zhao, S.: The effect of export marketing capabilities on export performance: an investigation of Chinese exporters. Journal of International Marketing 11, 32-55 (2003)

14. Williams, M. L.: Identifying the Organizational Routines in NEBIC Theory's Choosing Capability. HICCS, Hawaii (2003)

15. Marchand, D.A., Kettinger, W.J., Rollins, J.D.: Information Orientation: The Link to Business Performance. Oxford University Press, New York, USA (2002)

16. Qian, G., Li, L.: Profitability of small-and medium-sized enterprises in high-tech industries: the case of the biotechnology industry. Strategic Management Journal 24, 881-887 (2003) 
